\title{
New Oxidovanadium(IV) Mixed Ligand Complexes: Antidibetic, Anticancer activities and Cytotoxicity Study Using MTT Assay
}

\section{Sonaji Gayakwad}

Swami Ramanand Teerth Marathwada University

Dnyaneshwar Wankhede ( $\sim$ dswchem@yahoo.co.in )

Swami Ramanand Teerth Marathwada University https://orcid.org/0000-0002-5787-1013

Vikas Ragole

Swami Ramanand Teerth Marathwada University

Satish Maulage

Mrs. K. S. K. College

\section{Research Article}

Keywords: Molar conductance, magnetic susceptibilities, a-amylase, antimicrobial, Powder XRD

Posted Date: May 6th, 2021

DOI: https://doi.org/10.21203/rs.3.rs-486820/v1

License: (c) (i) This work is licensed under a Creative Commons Attribution 4.0 International License.

Read Full License 
New Oxidovanadium(IV) Mixed Ligand Complexes: Antidibetic, Anticancer activities and Cytotoxicity Study using MTT Assay

Sonaji Gayakwad ${ }^{1}$. Dnyaneshwar Wankhede ${ }^{1, *}$. Vikas Ragole ${ }^{1}$. Satish Maulage ${ }^{2}$

${ }^{1}$ School of Chemical Sciences, Swami Ramanand Teerth Marathwada University, Nanded-431606, Maharashtra State, India

${ }^{2}$ Department of Chemistry, Mrs. K. S. K. College, Beed-431122, Maharashtra State, India

Corresponding author e-mail: $\underline{\text { dswchem@yahoo.co.in }}$

ORCID id of Dnyaneshwar Wankhede: 0000-0002-5787-1013 


\section{Abstract}

Five new (HQ-1 to HQ-5) oxidovanadium(IV) mixed ligand complexes using 8hydroxyquinoline as primary ligand and amino acids like L-cystein, L-alanine, Lphenylalanine, L-threonine and L-serine as secondary ligands in 1:1:1 ratio were synthesized. All the complexes were characterized using various characterization techniques such as elemental analysis, IR, electronic, mass spectra, thermal (TGA/DTA) and powder XRD analysis, molar conductance and magnetic susceptibility measurements. Based on the results obtained all the complexes were proposed to have square pyramidal geometry. All the complexes were screened for their antibacterial activities against E. coli and antifungal activities against $C$. albicans. In vitro antidibetic activities of all the complexes were studied by screening them for $\alpha$-amylase inhibition activities. The complexes HQ-4 and HQ-5 were also screened for their anticancer activities against human cancer cells HepG2 using MTT assay.

\section{Graphical Abstract}

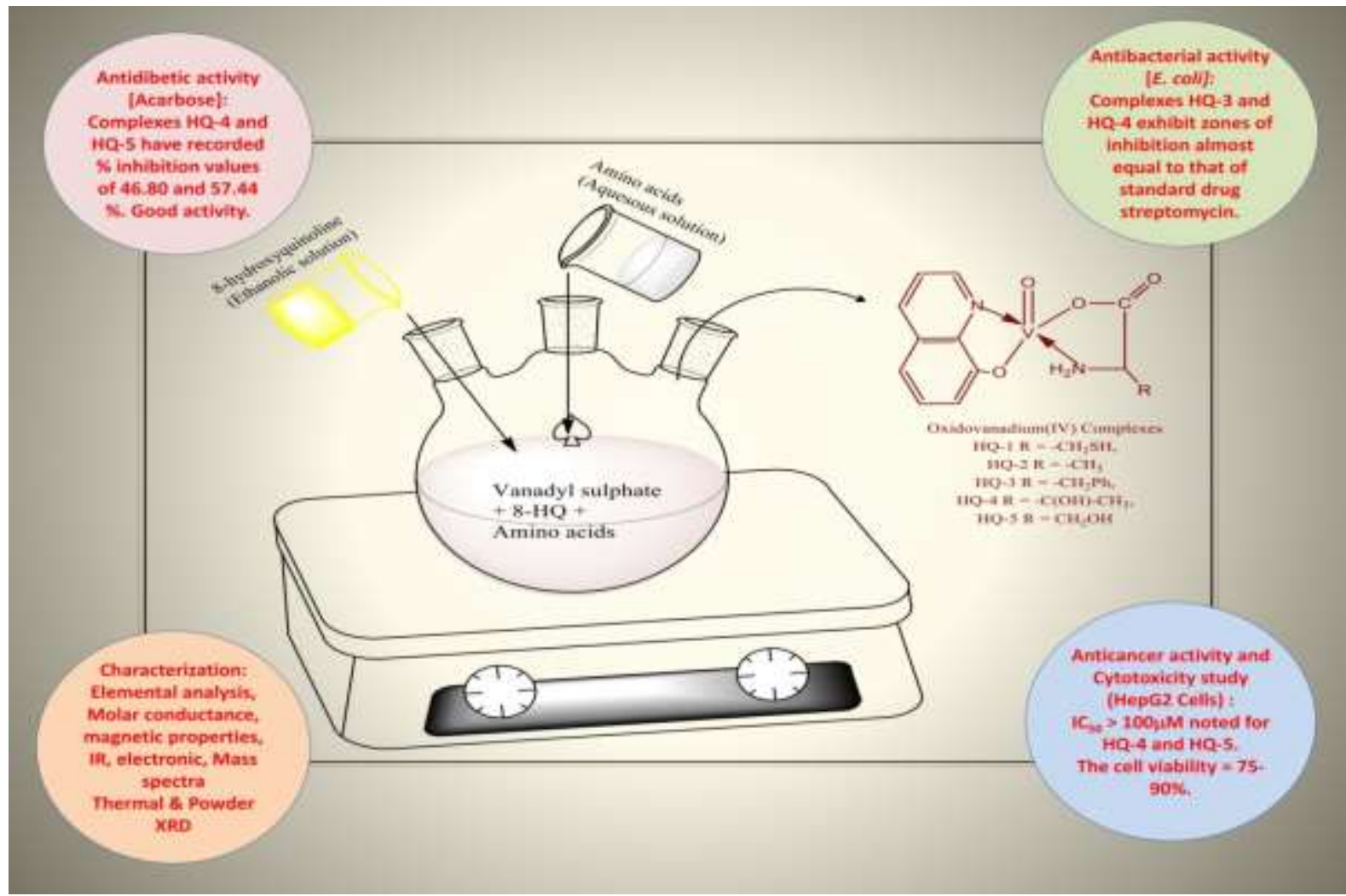

Keywords Molar conductance . magnetic susceptibilities . $\alpha$-amylase . antimicrobial . Powder XRD 


\section{Introduction}

Diabetes mellitus (DM) resulting from insulin deficiency or insulin resistance is a serious chronic disorder around the world [1-3]. The increasing population failing to this disease around the world has become a serious issue today. Two types of situations are identified regarding this disease viz. type $1 \mathrm{DM}$ called as insulin dependent DM and type 2 called as non-insulin dependent DM. Although various drugs are used to treat type 2 disease, the complications involved with this disease such as kidney failure, micro-and macrovascular disease, retinopathy, neuropathy and atherosclerosis has created an urgent need for the search of orally active drugs [1-3].

Vanadium is an important trace element and essential for human body [1, 4]. Vanadium compounds are known to possess insulin mimetic activity, inhibit lipolysis, decrease blood glucose levels (BGL) in animals and in clinical trials, and stimulate insulin secretion in experimental models of Diabetes Mellitus (DM) [5-10]. 8-hydroxyquinoline is monoprotic bidentate ligand and is widely used in complex formation [11]. 8-hydoxyquinoline and its metal complexes exhibit antiseptic, disinfectant and pesticide properties [12]. Mixed ligand complexes involving amino acids as secondary ligands are significant owing to their potential to act as models for enzyme metal ion substrate complexes [13].

We report synthesis of new oxidovanadium(IV) mixed ligand complexes using 8hydroxyquinoline and amino acids like L-cystein, L-alanine, L-phenylalanine, L-threonine and L-serine as ligands, their characterization using various characterization methods and their screening for antimicrobial, antidibetic, anticancer activities and cytotoxicity study using MTT assay.

\section{Materials and Methods}

\subsection{Materials}

Chemicals used in the present investigation were purchased from S. D. Fine Chemicals, Spectrochem Private Limited, Qualigens Fine Chemicals and Merck Chemicals. All the chemicals used were of AR grade. Solvents were double distilled and dried using molecular sieves before use [14].

\subsection{Methods}


Melting point or decomposition temperature for all the synthesized compounds was measured using a simple capillary tube method. Elemental analyses of complexes were done using Thermo finnigan (Model: Flash EA 1112 series) analyzer. Molar conductance values of all the synthesized complexes were measured by preparing $10^{-3} \mathrm{M}$ solutions in DMSO solvent using Equiptronics conductivity meter with an inbuilt magnetic stirrer (Model:Eq-664) at room temperature. Magnetic susceptibilities were determined on the SES Instrument's magnetic susceptibility Gouy's balance (Model:EMU-50) at room temperature using copper(II) sulphate as a standard.

IR spectra were recorded as $\mathrm{KBr}$ pellets in the region of $4000-400 \mathrm{~cm}^{-1}$ on a Perkin Elmer Spectrophotometer. Electronic spectra were recorded by preparing $10^{-3} \mathrm{M}$ solutions of complexes in DMSO using Shimadzu UV-1800 UV/Visible Scanning spectrophotometer (double beam). Mass spectra were recorded using Alliance 2795 Q-TOF Micromass mass spectrometer. The TGA/DTA curves were recorded using DTG $60 \mathrm{H}$ module with heating rate $10.00 \mathrm{k} / \mathrm{min}$. The experiments were carried out in a nitrogen atmosphere with heating rate of $10.00 \mathrm{~K} / \mathrm{Min}$ and in temperature range 30 to $1000^{\circ} \mathrm{C}$ using alumina crucible. The amount of samples taken was $9 \mathrm{mg}$. The Powder XRD was recorded on an Ultima IV instrument with $\mathrm{X}$-Ray 40kV/20mA.

\subsection{Synthesis of mixed ligand Complexes}

General procedure used for synthesis of mixed ligand complexes is given below:

To an aqueous solution $(20 \mathrm{~mL})$ of vanadyl sulphate $(1.63 \mathrm{~g}, 0.01 \mathrm{~mol})$ an ethanolic solution (20 mL) of 8-hydroxyquinoline (1.45 g, 0.01 mole) was added. The mixture was stirred for $30 \mathrm{~min}$ at room temperature. To this reaction mixture an aqueous solution $(20 \mathrm{~mL})$ of respective amino acid $(0.01 \mathrm{~mol})$ was added drop wise with constant stirring. The resulting reaction mixture was then allowed to stir at room temperature. After $5 \mathrm{~h}$ black coloured complexes were precipitated, which were filtered, washed with cold distilled water followed by ethanol. The complexes were dried at room temperature and used for further study. Fig. 1 represents the generalized proposed structure of all the synthesized mixed ligand complexes. 


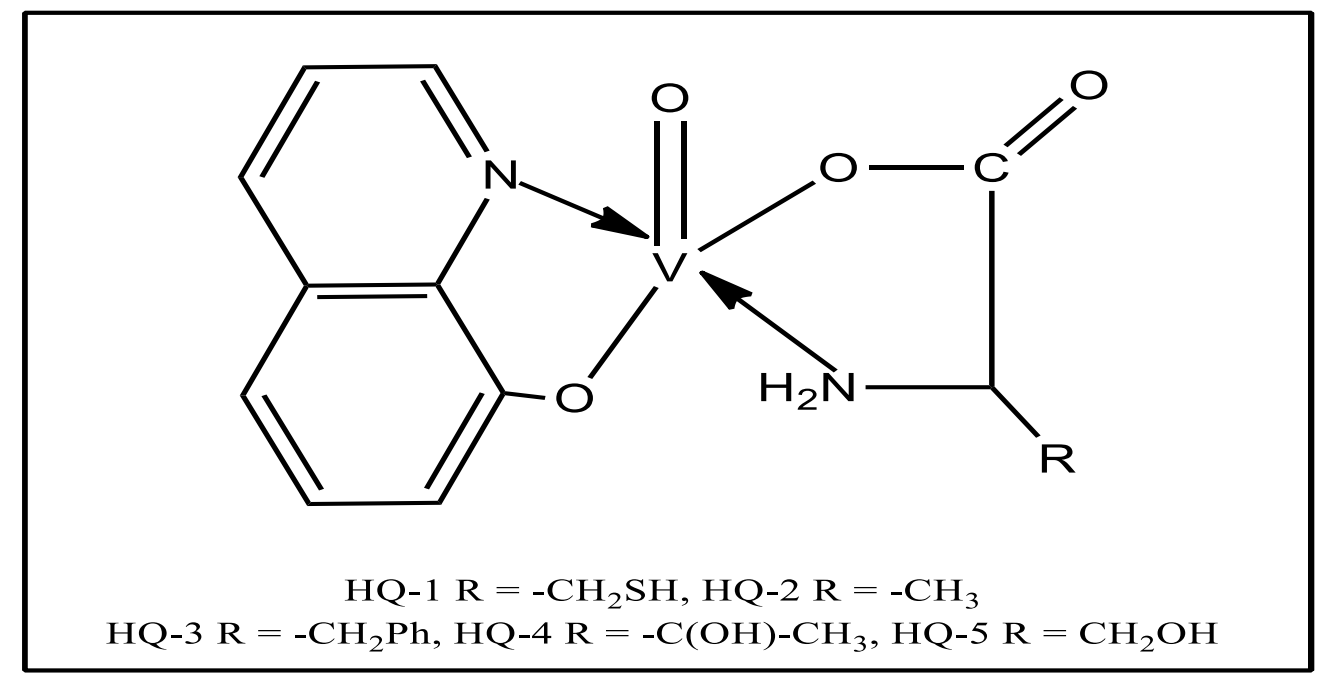

Fig. 1 Generalized proposed structure of all the synthesized mixed ligand complexes

\subsection{Antimicrobial activity}

The complexes were screened for their antibacterial activity against bacterial pathogen E. coli using well plate method. The complexes $(10 \mathrm{mg})$ were dissolved in DMSO, so as to prepare solution of concentration $1000 \mu \mathrm{g} / \mathrm{mL}$. The test solution was spread uniformly on the surface of agar medium in a Petri plate by using spreader. In each plate up to four discs were used.

Similarly all the complexes were screened for their antifungal activity using well diffusion method. In this method the agar plate surface is inoculated by spreading a volume of the microbial inoculums over the entire agar surface. Then, a hole with a diameter of 6 to $8 \mathrm{~mm}$ is punched aseptically with a sterile cork borer or a tip and a volume $(20-100 \mathrm{~mL})$ of the antimicrobial agent or extract solution at desired concentration is introduced into the well. Then, Agar plates are incubated under suitable conditions depending upon the test microorganism. The antimicrobial agent diffuses in the agar medium and inhibits the growth of the microbial strain tested [15] against $C$. albicans fungi and is compared with standard drug used. The inhibitory concentration used for testing was $1000 \mu \mathrm{g} / \mathrm{mL}$.

\subsection{Anti-diabetic activity using $\alpha$-amylase inhibition}

\subsubsection{Importance $\alpha$-amylase enzyme in the body}

In humans, the digestion of starch involves several stages. Initially, partial digestion by the salivary amylase results in the degradation of polymeric substrates into shorter oligomers. Later on in the gut these are further hydrolyzed by pancreatic $\alpha$-amylases into maltose, 
maltotriose and small malto-oligosaccharides. The digestive enzyme ( $\alpha$-amylase) is responsible for hydrolyzing dietary starch (maltose), which breaks down into glucose prior to absorption. Inhibition of $\alpha$-amylase can lead to reduction in post prandial hyperglycemia in diabetic condition [16-17]. Treatment of diabetes include improvement of the activity of insulin at the objective tissues, with the utilization of sensitizers (biguanides, thiozolidinediones); incitement of endogenous insulin discharge with the utilization of sulfonylureas (glibenclamide, glimepiride) and decrease of the interest for insulin utilizing particular enzyme inhibitors (Acarbose, miglitol)

\subsubsection{Assay of Amylase Inhibition}

In vitro amylase inhibition was studied using method of Bernfeld [18]. A $100 \mu \mathrm{L}(100 \mu \mathrm{g} /)$ of the test extract was allowed to react with $200 \mu \mathrm{L}$ of $\alpha$-amylase enzyme (Hi media 638) and $100 \mu \mathrm{L}$ of $2 \mathrm{mM}$ of phosphate buffer (pH-6.9). After 20 min incubation, $100 \mu \mathrm{L}$ of $1 \%$ starch solution was added. The same procedure was performed for the controls where $200 \mu \mathrm{L}$ of the enzyme was replaced by buffer. After incubation for $5 \mathrm{~min}, 500 \mu \mathrm{L}$ of dinitrosalicylic acid reagent was added to both control and test samples. They were kept in boiling water bath for $5 \mathrm{~min}$. The absorbance was recorded at $540 \mathrm{~nm}$ using spectrophotometer and the percentage inhibition of $\alpha$-amylase enzyme was calculated using the formula (1) given below:

Percent Inhibition $(\%)=\frac{[(\text { Abs } 540(\text { control })-\text { Abs } 540(\text { extract })]}{A b s 540(\text { control })} \times 100$

Suitable reagent blank and inhibitor controls were simultaneously carried out.

\subsection{Anticancer activity and cytotoxicity study using MTT assay}

The anticancer activity of complexes HQ-4 and HQ-5 were determined using MTT [3-(4,5dimethylthiazol-2-yl)-2,5-diphenyl tetrazolium bromide] assay against human liver cancer cell lines HepG2 to assess the cytotoxicity [19-20]. The cancer cell line used in this work was selected due to easy availability and wide use found in literature survey with cisplatin.

Cells were incubated at a concentration of $1 \times 10^{4}$ cells/ in culture medium for $24 \mathrm{~h}$ at $37^{\circ} \mathrm{C}$ and $5 \% \mathrm{CO}_{2}$. Cells were seeded at a concentration $(70 \mu \mathrm{L}) 10^{4}$ cells/well in $100 \mu \mathrm{L}$ culture medium and $100 \mu \mathrm{L}$ herbal extracts into micro plates respectively (tissue culture grade, and 96 wells). Control wells were incubated with DMSO (0.2\% in PBS) and cell line. All 
Samples were incubated in triplicate. Controls were maintained to determine the control cell survival and the percentage of live cells after culture. Cell cultures were incubated for $24 \mathrm{~h}$ at $37^{\circ} \mathrm{C}$ and $5 \% \mathrm{CO}_{2}$ in $\mathrm{CO}_{2}$ incubator. After incubation the medium was completely removed and added $20 \mu \mathrm{L}$ of MTT reagent (5mg/min PBS). After addition of MTT, cells incubated for 4h at $37^{\circ} \mathrm{C}$ in $\mathrm{CO}_{2}$ incubator. The wells were observed for formazan crystal formation under microscope. The yellowish MTT was reduced to dark coloured formazan by viable cells only. After removing the medium completely added $200 \mu \mathrm{L}$ of DMSO (kept for $10 \mathrm{~min}$ ) and incubated at $37^{\circ} \mathrm{C}$ (wrapped with aluminium foil). Triplicate samples were analyzed by measuring the absorbance of each sample by microplate reader at a wavelength of $550 \mathrm{~nm}$. Measurements were performed and the concentration required for a $50 \%$ inhibition of viability $\left(\mathrm{IC}_{50}\right)$ was determined graphically.

\section{Result and Discussion}

\subsection{Physicochemical data}

The synthesis of mixed ligand complexes of vanadium using 8-hydroxyquinoline and amino acids in 1:1:1 proportion can be represented as follows:

$$
\mathrm{VOSO}_{4}+\mathrm{HQ}+\mathrm{HL} \longrightarrow[\mathrm{VO}(\mathrm{Q})(\mathrm{L})]
$$

Where, HQ = 8-hydroxyquinoline and $\mathrm{HL}=\mathrm{L}$-Amino Acids. All the synthesized complexes are obtained in 70-78\% yield, black coloured, non-hygroscopic and thermally stable indicating presence strong metal-ligand bonding. The complexes are insoluble in common organic solvents, but are found to be soluble in DMSO and DMF.

\subsection{Molar conductance}

The molar conductance values recorded for all the synthesized complexes $(0.12-0.29$ Mhos $\mathrm{mol}^{-1} \mathrm{~cm}^{-2}$ ) are very low which indicates non-electrolytic nature of complexes [21].

\subsection{Magnetic measurements}

The observed values of magnetic moments (1.72 to 1.87 B.M.) indicate presence of one unpaired electron in these complexes [21]. The results obtained from molar conductance and 
magnetic susceptibility measurements along with elemental analysis data recorded for all the synthesized mixed ligand complexes are represented in Table 1.

Table 1 Elemental analysis, molar conductance and magnetic susceptibility values

\begin{tabular}{|c|c|c|c|c|c|c|c|c|}
\hline \multirow{2}{*}{ Complexes } & \multicolumn{6}{|c|}{$\begin{array}{l}\text { Elemental Analysis } \\
\text { Calculated/Found (\%) }\end{array}$} & \multirow{2}{*}{$\begin{array}{l}\text { Molar Conductance } \\
\left(\mathrm{Mhos}^{-1} \mathrm{~cm}^{-2}\right)\end{array}$} & \multirow{2}{*}{$\begin{array}{r}\mu_{\text {eff }} \\
\text { (B.M. }\end{array}$} \\
\hline & C & $\mathrm{H}$ & $\mathrm{N}$ & $\mathrm{O}$ & $\mathrm{S}$ & $\mathrm{M}(\mathrm{V})$ & & \\
\hline $\begin{array}{c}\mathrm{HQ}-1 \\
\mathrm{C}_{12} \mathrm{H}_{12} \mathrm{~N}_{2} \mathrm{O}_{4} \mathrm{SV}\end{array}$ & $\begin{array}{c}43.51 \\
(43.47)\end{array}$ & $\begin{array}{c}3.65 \\
(3.62)\end{array}$ & $\begin{array}{c}8.46 \\
(8.45)\end{array}$ & $\begin{array}{c}19.32 \\
(19.34)\end{array}$ & $\begin{array}{c}9.68 \\
(9.66)\end{array}$ & $\begin{array}{c}15.38 \\
(15.39)\end{array}$ & 0.12 & 1.75 \\
\hline $\begin{array}{c}\mathrm{HQ}-2 \\
\mathrm{C}_{12} \mathrm{H}_{12} \mathrm{~N}_{2} \mathrm{O}_{4} \mathrm{~V}\end{array}$ & $\begin{array}{c}48.18 \\
(48.13)\end{array}$ & $\begin{array}{c}4.04 \\
(4.01)\end{array}$ & $\begin{array}{c}9.36 \\
(9.35)\end{array}$ & $\begin{array}{l}21.39 \\
(21.39)\end{array}$ & --- & $\begin{array}{l}17.03 \\
(17.04)\end{array}$ & 0.21 & 1.84 \\
\hline $\begin{array}{c}\mathrm{HQ}-3 \\
\mathrm{C}_{18} \mathrm{H}_{16} \mathrm{~N}_{2} \mathrm{O}_{4} \mathrm{~V}\end{array}$ & $\begin{array}{l}57.61 \\
(57.56)\end{array}$ & $\begin{array}{c}4.30 \\
(4.26)\end{array}$ & $\begin{array}{c}7.46 \\
(7.45)\end{array}$ & $\begin{array}{l}17.05 \\
(17.05)\end{array}$ & --- & $\begin{array}{c}13.57 \\
(13.59)\end{array}$ & 0.18 & 1.87 \\
\hline $\begin{array}{c}\mathrm{HQ}-4 \\
\mathrm{C}_{13} \mathrm{H}_{14} \mathrm{~N}_{2} \mathrm{O}_{5} \mathrm{~V}\end{array}$ & $\begin{array}{c}47.43 \\
(47.38)\end{array}$ & $\begin{array}{c}4.29 \\
(4.25)\end{array}$ & $\begin{array}{c}8.51 \\
(8.50)\end{array}$ & $\begin{array}{l}24.30 \\
(24.30)\end{array}$ & --- & $\begin{array}{c}15.47 \\
(15.49)\end{array}$ & 0.26 & 1.72 \\
\hline $\begin{array}{c}\mathrm{HQ-5} \\
\mathrm{C}_{12} \mathrm{H}_{12} \mathrm{~N}_{2} \mathrm{O}_{5} \mathrm{~V}\end{array}$ & $\begin{array}{c}45.73 \\
(45.68)\end{array}$ & $\begin{array}{c}3.84 \\
(3.80)\end{array}$ & $\begin{array}{c}8.89 \\
(8.88)\end{array}$ & $\begin{array}{l}25.38 \\
(25.38)\end{array}$ & --- & $\begin{array}{l}16.16 \\
(16.18)\end{array}$ & 0.29 & 1.73 \\
\hline
\end{tabular}

\subsection{IR spectra}

The broad peak observed in the range of 3410 to $3442 \mathrm{~cm}^{-1}$ due to symmetric stretching of O$\mathrm{H}$ bond in free 8-hydroxyquinoline molecule was found to be absent in case of complexes which indicates complex formation between vanadium and 8-hydroxyquinoline through oxygen atom of $-\mathrm{OH}$ group.

The broad peak at $2920-2972 \mathrm{~cm}^{-1}$ due to $-\mathrm{NH}$ vibrations of free amino acids are shifted to higher wave number in the range of $2981-3057 \mathrm{~cm}^{-1}$ in the spectra of metal complexes which indicates amino group bonded through nitrogen atom with metal [13]. The $\mathrm{C}=\mathrm{N}$ stretching vibration observed at $1580 \mathrm{~cm}^{-1}$ in free 8-hydroxyquinoline ligand is shifted to lower wave number up to $1460-1465 \mathrm{~cm}^{-1}$ in the spectra of complexes. This indicates coordination of 8 hydroxyquinoline molecule with vanadium through ternary nitrogen.

The asymmetric and symmetric ( $\left.\mathrm{COO}^{-}\right)$bands observed in the region 1580-1597 and 1402$1408 \mathrm{~cm}^{-1}$ in free amino acids were observed to be shifted to lower wave numbers region of 1571-1575 and 1373-1377 $\mathrm{cm}^{-1}$ respectively in the spectra of complexes. This indicates bonding of $\mathrm{COO}^{-}$group with metal with oxygen atom of carboxylic group of amino acids. The band observed between $945-950 \mathrm{~cm}^{-1}$ in the spectra of complexes indicates $v(\mathrm{~V}=\mathrm{O})$ stretching vibrations. Finally the bands observed in the range of $445-447 \mathrm{~cm}^{-1}$ and $621-632$ $\mathrm{cm}^{-1}$ indicates $v(\mathrm{M}-\mathrm{N})$ and $v(\mathrm{M}-\mathrm{O})$ bonding in complexes respectively.

\subsection{Electronic spectra}


The electronic absorption spectra of synthesized mixed ligand complexes were recorded using freshly prepared solution in DMSO at room temperature. The electronic spectra of all the five complexes show three absorption bands.

The first band at 203-264 $\mathrm{nm}$ indicates $\pi \rightarrow \pi^{*}$ transition due to aromatic rings of ligand. The second peak observed in the range 364-501 nm in electronic spectra of complexes indicate charge transfer transition from ligand to metal atom (LMCT) [21].

Third absorption band observed in the region 479-791 $\mathrm{nm}$ in electronic spectra of complexes can be caused by $\mathrm{d} \rightarrow \mathrm{d}^{*}$ transition of the central metal vanadium [22]. The results obtained from electronic spectra of all the synthesised complexes indicated presence of square pyramidal geometry in all these complexes [23].

\subsection{Mass spectra}

The ESI-MS spectra of complexes HQ-4 and HQ-5 were recorded as a representative case. The peaks of appreciable intensity have been observed in both these complexes viz. peaks at m/z 146, 252, 301, 338, 355, 437, 453, 582, 727 and 749 for HQ-4 complex and 146, 252, 355, 301, 413, 582, 727 and 749 for HQ-5 complex.

Although molecular ion peaks are not observed in both these spectra, the peak at $\mathrm{m} / \mathrm{z} 338$ in mass spectrum of HQ-4 and at m/z 301 in mass spectrum of HQ-5 complexes is nearest to the composition of $\mathrm{HQ}-\mathbf{4}\left[\mathrm{C}_{\mathbf{1 3}} \mathrm{H}_{\mathbf{1 4}} \mathbf{N}_{\mathbf{2}} \mathrm{O}_{\mathbf{5}} \mathrm{V}\right]$ and $\mathrm{HQ-5}\left[\mathrm{C}_{\mathbf{1 2}} \mathrm{H}_{\mathbf{1 2}} \mathbf{N}_{\mathbf{2}} \mathrm{O}_{5} \mathrm{~V}\right]$ respectively [24].

\subsection{Thermal analysis (TGA/DTA)}

The TGA and DTA curves were recorded for mixed ligand complexes HQ-1 and HQ-2 as a representative case. Two major weight loss steps are observed in both these complexes. For complex HQ-1 the weight loss of $-37.36 \%$ observed in first step in the temperature range $220-300^{\circ} \mathrm{C}$ is attributed to loss of coordinated 8-hydroxyquinoline molecule. While the second major weight loss of $-47.13 \%$ in the temperature range $300-600^{\circ} \mathrm{C}$ is attributed to loss of another coordinated ligand molecule.

For complex HQ-2 the first weight loss is observed in the temperature range $250-400^{\circ} \mathrm{C}$ which is attributed to loss of coordinated 8-hydroxyquinoline ligand molecule. While the second weight loss in the temperature range $400-650^{\circ} \mathrm{C}$ indicates loss of second ligand molecule. 
The DTA curve of both these complexes exhibit two broad peaks in the range of $300-650^{\circ} \mathrm{C}$. It was observed that decomposition of complex is started at $300^{\circ} \mathrm{C}$ and completed at 600 $650^{\circ} \mathrm{C}$. After complete decomposition, formation of fine powder of metal atom with reducing gaseous products like $\mathrm{CO}, \mathrm{NH}_{3}$ etc. was observed which confirms the loss of both coordinated ligands from metal during decomposition of complexes [25].

\subsection{Powder XRD analysis}

The nature of synthesized mixed ligand complexes were studied by powder X-ray method. The XRD pattern indicates microcrystalline nature of complexes. The particle sizes of complexes were calculated using Scherer's formula [26] given as in equation (2).

Particle size $(D)=\frac{0.9 \lambda}{\beta \cos \theta}$

Where $\lambda=$ wavelength of $\mathrm{x}$-ray radiation, $\beta=\mathrm{FWHM}$ and $\theta=$ diffraction angle.

The mean particle size of complexes HQ-1, HQ-2, HQ-3, HQ-4 and HQ-5 is found to be $15.75,24.98,10.60,37.26$ and $25.86 \mathrm{~nm}$ respectively. The inter planner spacing (d) of complexes were calculated by using Bragg's equation (3).

$n \lambda=2 d \operatorname{Sin} \theta$

Where, $\lambda=$ Wavelength of $x$-ray, and $\theta=$ is the angle of diffraction. The results obtained from powder XRD analysis of all the complexes are represented in Table 2.

Table 2 Powder XRD analysis

\begin{tabular}{ccccccc}
\hline Complex & Reflexes & $2 \theta$ & $\begin{array}{c}\text { Miller } \\
\text { Indices }\end{array}$ & $\begin{array}{c}\text { Inter Planner } \\
\text { Spacing d }\left(\mathrm{A}^{\circ}\right)\end{array}$ & $\begin{array}{c}\text { Crystal Size } \\
\text { D }(\mathrm{nm})\end{array}$ & FWHM \\
\hline & Peak1 & 9.94 & 111 & 8.89 & 08.92 & 1.5587 \\
& Peak2 & 12.81 & 210 & 6.90 & 31.18 & 0.4474 \\
$\mathrm{C}_{12} \mathrm{H}_{12} \mathrm{~N}_{2} \mathrm{O}_{4} \mathrm{SV}$ & Peak3 & 18.85 & 311 & 4.70 & 26.62 & 0.5278 \\
$(\mathrm{HQ}-1)$ & Peak4 & 22.79 & 400 & 3.95 & 03.18 & 4.9398 \\
& Peak5 & 28.50 & 422 & 3.12 & 08.85 & 1.6146 \\
& & & Average crystal size & $15.75 \mathrm{~nm}$ & \\
& Peak1 & 7.41 & 111 & 11.9 & 24.50 & 0.5669 \\
$\mathrm{C}_{12} \mathrm{H}_{12} \mathrm{~N}_{2} \mathrm{O}_{4} \mathrm{~V}$ & Peak2 & 11.90 & 220 & 7.42 & 28.51 & 0.4888 \\
$(\mathrm{HQ}-2)$ & Peak3 & 22.65 & 511 & 3.92 & 22.52 & 0.6275 \\
& 24.15 & 521 & 3.68 & 24.38 & 0.5813 \\
& & & Average crystal size & $24.98 \mathrm{~nm}$ & \\
& Peak1 & 11.96 & 111 & 7.39 & 07.60 & 1.8320 \\
$\mathrm{C}_{18} \mathrm{H}_{16} \mathrm{~N}_{2} \mathrm{O}_{4} \mathrm{~V}$ & Peak2 & 19.90 & 220 & 4.45 & 12.97 & 1.0847 \\
$(\mathrm{HQ}-3)$ & Peak3 & 22.97 & 311 & 3.86 & 07.42 & 1.9058 \\
& Peak4 & 30.80 & 420 & 2.89 & 14.68 & 0.9789 \\
& & \multicolumn{7}{c}{ Average crystal size } & $10.60 \mathrm{~nm}$ & \\
& Peak1 & 11.89 & 111 & 7.44 & 32.68 & 0.4265 \\
& Peak2 & 13.13 & 200 & 6.74 & 47.59 & 0.2932 \\
& Peak3 & 19.18 & 220 & 4.62 & 55.17 & 0.2548 \\
\hline
\end{tabular}




\begin{tabular}{ccccccc}
\hline $\mathrm{C}_{13} \mathrm{H}_{14} \mathrm{~N}_{2} \mathrm{O}_{5} \mathrm{~V}$ & Peak4 & 22.73 & 311 & 3.90 & 15.84 & 0.8920 \\
$(\mathrm{HQ}-4)$ & Peak5 & 24.20 & 222 & 3.67 & 24.19 & 0.5859 \\
& Peak6 & 27.75 & 400 & 3.21 & 48.09 & 0.2969 \\
& & \multicolumn{5}{c}{$\begin{array}{c}\text { Average crystal size } \\
\end{array}$} \\
& Peak1 & 11.96 & 111 & 7.39 & $37.26 \mathrm{~nm}$ & \\
& Peak2 & 13.21 & 200 & 6.70 & 49.11 & 0.4213 \\
& Peak3 & 20.24 & 221 & 4.38 & 17.44 & 0.873 \\
$\mathrm{C}_{12} \mathrm{H}_{12} \mathrm{~N}_{2} \mathrm{O}_{5} \mathrm{~V}$ & Peak4 & 22.64 & 311 & 3.92 & 22.14 & 0.6385 \\
$(\mathrm{HQ}-5)$ & Peak5 & 24.43 & 222 & 3.63 & 07.54 & 1.8807 \\
& & \multicolumn{5}{c}{ Average crystal size } \\
\hline
\end{tabular}

\subsection{Antimicrobial activity}

The complexes HQ-3 and HQ-4 exhibited zones of inhibition 20 and $19 \mathrm{~mm}$ respectively which is almost equal to that of standard drug streptomycin $(20 \mathrm{~mm})$. Hence these two complexes exhibit excellent antimicrobial activity against E. Coli. Out of the remaining complexes, HQ-1 and HQ-5 exhibited moderate to good activity with the zone of inhibition values of $17 \mathrm{~mm}$ and $12 \mathrm{~mm}$ respectively, whereas the complex HQ-2 exhibited moderate activity with the zone of inhibition $9 \mathrm{~mm}$.

Fig. 2 represents results obtained from antibacterial screening of all the complexes.

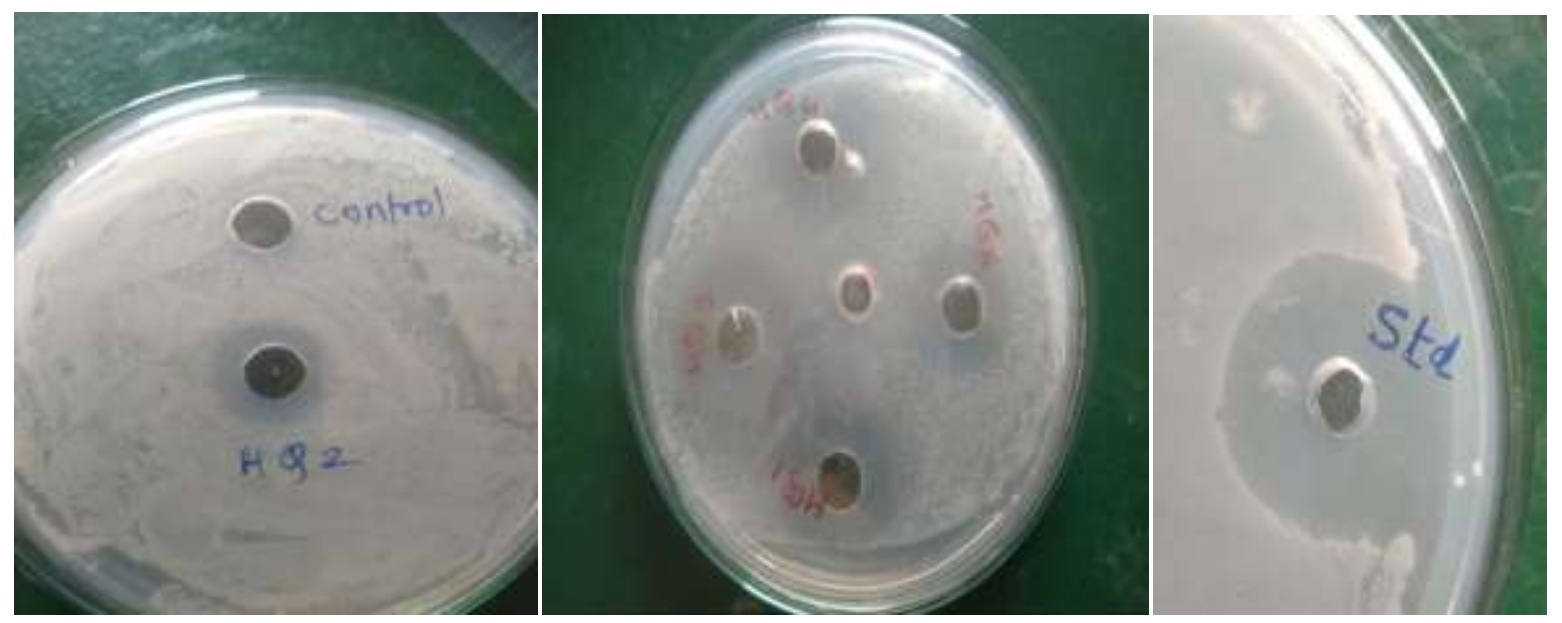

Fig. 2 Antibacterial activity against E. coli

All the complexes exhibited very poor antifungal activity with zone of inhibition values ranging from 0 to $7 \mathrm{~mm}$ as compared to standard drug with zone of Inhibition value of $16 \mathrm{~mm}$ $[13,27-28]$.

Fig. 3 represents results obtained for antifungal screening of all the mixed ligand complexes. 


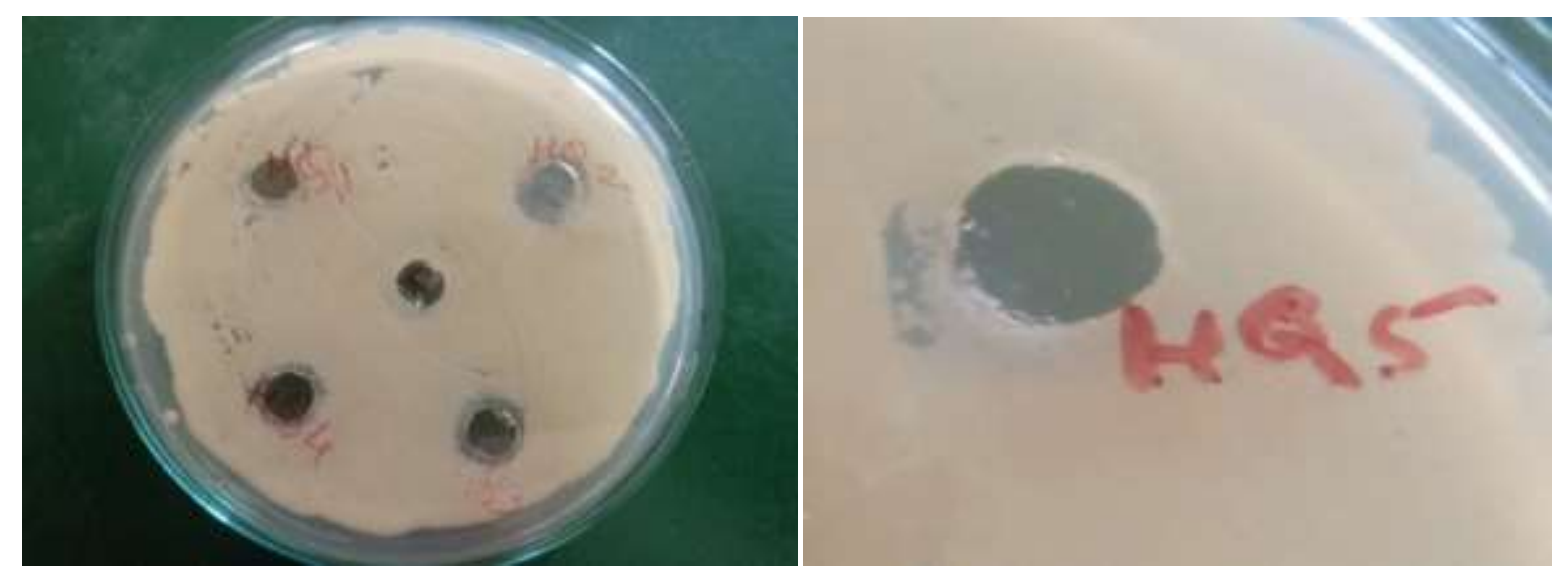

Fig. 3 Antifungal activity against C. albicans

\subsection{Anti-diabetic activity using $\alpha$-amylase inhibition}

Table 3 given below represents the results obtained from antidibetic activity i.e. percent inhibition of $\alpha$-amylase inhibitory assay for all the synthesized mixed ligand complexes.

Table 3 Antidibetic activity using $\alpha$-amylase inhibition

\begin{tabular}{cccc}
\hline Sample Code & Concentration $(\mu \mathrm{g} / \mathbf{m L})$ & ABS at 540 $\mathbf{~ n m}$ & \% inhibition \\
\hline Blank & --- & 0.47 & --- \\
HQ-1 & 1000 & 0.38 & 19.14 \\
$\mathrm{C}_{12} \mathrm{H}_{12} \mathrm{~N}_{2} \mathrm{O}_{4} \mathrm{SV}$ & 1000 & 0.37 & 21.27 \\
$\mathrm{HQ}-2$ & 1000 & 0.46 & 02.12 \\
$\mathrm{C}_{12} \mathrm{H}_{12} \mathrm{~N}_{2} \mathrm{O}_{4} \mathrm{~V}$ & 1000 & 0.25 & 46.80 \\
$\begin{array}{c}\mathrm{HQ}-3 \\
\mathrm{C}_{18} \mathrm{H}_{16} \mathrm{~N}_{2} \mathrm{O}_{4} \mathrm{~V}\end{array}$ & 1000 & 0.20 & 57.44 \\
$\begin{array}{c}\mathrm{HQ}-4 \\
\mathrm{C}_{13} \mathrm{H}_{14} \mathrm{~N}_{2} \mathrm{O}_{5} \mathrm{~V}\end{array} \begin{array}{c}\mathrm{HQ}-5 \\
\mathrm{C}_{12} \mathrm{H}_{12} \mathrm{~N}_{2} \mathrm{O}_{5} \mathrm{~V}\end{array}$ & 1000 & 0.13 & 72.34 \\
\hline Standard - Acarbose & & & \\
\hline
\end{tabular}

The complexes HQ-4 and HQ-5 have recorded \% inhibition values of 46.80 and $57.44 \%$ which means these complexes show good activity as compared to standard acarbose (72.34\%). The remaining three complexes HQ-1, HQ-2 and HQ-3 exhibited poor activities (i.e. $19.14,21.27$ and $02.21 \%$ inhibition) respectively.

\subsection{Anticancer activities and cytotoxicity study using MTT assay}

To evaluate cytotoxicity two of the synthesized complexes HQ-4 and HQ-5, against human hepatocarcinoma (HepG2) cells, were incubated with different doses $(10,30$ and $100 \mu \mathrm{g} / \mathrm{mL})$ 
for $24 \mathrm{~h}$ and cell viability was determined by the MTT assay. Table 4 represents results obtained from anticancer activity and cytotoxicity study using MTT assay.

Table 4 Anticancer activity and cytotoxicity study using MTT Assay

\begin{tabular}{ccccc}
\hline Complex & $\begin{array}{c}\text { Concentration } \\
(\boldsymbol{\mu g} / \mathbf{m L})\end{array}$ & $\begin{array}{c}\text { Cell Viability } \\
(\boldsymbol{\%})\end{array}$ & $\begin{array}{c}\text { Cell inhibition } \\
(\boldsymbol{\%})\end{array}$ & $\begin{array}{c}\text { IC50 } \\
(\boldsymbol{\mu M})\end{array}$ \\
\hline $\mathrm{HQ}-4$ & 10 & 87.45 & 12.55 & \\
$\mathrm{C}_{13} \mathrm{H}_{14} \mathrm{~N}_{2} \mathrm{O}_{5} \mathrm{~V}$ & 30 & 82.75 & 17.25 & $>100$ \\
& 100 & 77.32 & 22.68 & \\
$\mathrm{HQ}-5$ & 10 & 88.48 & 11.52 & $>100$ \\
$\mathrm{C}_{12} \mathrm{H}_{12} \mathrm{~N}_{2} \mathrm{O}_{5} \mathrm{~V}$ & 30 & 85.69 & 14.31 & \\
Standard & 100 & 75.92 & 24.08 & \\
5-FU & 10 & 62.05 & 37.95 & \\
(Fluorouracil) & 30 & 53.68 & 46.32 & \\
\hline
\end{tabular}

The $\mathrm{IC}_{50}$ values above $100 \mu \mathrm{M}$ are noted for both these complexes which indicate both these complexes were able to inhibit proliferation of the cancer cells HepG2 [19]. The cell viability values are within expected range i.e. $75-90 \%$ which indicates these complexes are more toxic to cancer cells than normal cells. Considering all these observed results both these complexes could be considered as potential anticancer agents.

\section{Conclusions}

All the complexes (HQ-1 to HQ-5) are proposed to have square pyramidal geometry. The complexes HQ-3 and HQ-4 exhibited excellent antibacterial activities against E. Coli i.e. close to that of standard streptomycin which seems to be inspiring and indicating towards potential of these compounds to act as antibacterial agents.

The complexes HQ-4 and HQ-5 show good percent inhibition of $\alpha$-amylase activities as compared to standard acarbose and thus good antidibetic activities. The complexes HQ-4 and HQ-5 were screened for their anticancer activities and cytotoxicity studies using MTT assay as a representative case. The $\mathrm{IC}_{50}$ values (below $50 \mu \mathrm{M}$ ) recorded indicated towards the potential of these complexes to act as anticancer agents.

\section{Compliance with Ethical Standards}

Conflicts of interest There is no conflicts of interests.

\section{References}


1. H. Zhang, Y. Yuetao, F. Dawei, W. Yipeng, Q, Song, Hindawi Publishing Corporation Evidence-Based Complementary and Alternative Medicine 2011. DOI: $10.1155 / 2011 / 691067$

2. G. Mariappan, B.P. Saha, S. Datta, D. Kumar, P.K. Haldar, J. Chem. Sci. 123(3), 335 (2011)

3. S.N. Shukla, P. Gaur, S. Jhariya, B. Chaurasia, P. Vaidya, D. Dehariya, M. Azam, Chem. Sci. Trans. 7(3), 424 (2018)

DOI: $10.7598 /$ cst2018.1509

4. B. Mukherjee, B. Patra, S. Mahapatra, P. Banerjee, A. Tiwari, M. Chatterjee, Toxicology Lett. 150 (2), 135 (2004)

DOI: 10.1016/j.toxlet.2004.01.009

5. J. Korbecki, I. Baranowska-Bosiacka, I. Gutowska, D. Chlubek, Acta Biochim. Pol. 59(2), 195, (2012)

6. D.C. Crans, J. Inorg. Biochem. 80(1-2), 123 (2000)

DOI: $10.1016 / \mathrm{s} 0162-0134(00) 00048-9$

7. G.R. Willsky, L.H. Chi, M. Godzala, P.J. Kostyniak, J.J. Smee, A.M. Trujillo, J.A. Alfano, W. Ding, Z. Hu, D.C. Crans, Coord. Chem. Rev. 255(19-20), 2258 (2011)

DOI: $10.1016 /$ j.ccr.2011.06.015

8. C. Yuan, L. Lu, X. Gao, Y. Wu, M. Guo, Y. Li, X. Fu, M. Zhu, M., J. Biol. Inorg. Chem. 14, 841 (2009)

DOI: $10.1007 / \mathrm{s} 00775-009-0496-6$

9. M. Li, W. Ding, J.J. Smee, B. Baruah, G.R. Willsky, D.C. Crans, Biometals. 22(6), 895 (2009)

DOI: $10.1007 / \mathrm{s} 10534-009-9241-4$

10. E.V. Fedorova, A.V. Buryakina, A.V. Zakharov, D.A. Filmonov, V.V. Poroikov, Plos One. 9 (7), 1 (2014)

DOI: https://doi.org/10.1371/journal.pone.0100386

11. W. Sanoja, J.D. Martinez, M.L. Araujo, F. Brito, L. Hernandez, E. Del Carpio, V. Lubes, J. Mol. Liqs. 197, 223 (2014)

DOI: http://dx.doi.org/10.1016/j.molliq.2014.05.012

12. L.E. Sarmiento, M. Rodriguez, L. Echevarria, V. Lubes, J. Sol. Chem. 39, 1484 (2010)

DOI: $10.1007 / \mathrm{s} 10953-010-9603-0$ 
13. S.S. Patil, G.A. Thakur, M.M. Shaikh, ISRN Pharmaceutics, (2011) DOI: $10.5402 / 2011 / 168539$

14. A. I. Vogel, Textbook of Practical Organic Chemistry, $5^{\text {th }}$ edition, Longman, London, (1989)

15. M. Balouiri, M. Sadiki, S. Koraichi Ibnsouda, J. Pharma. Analysis. 6, 71 (2016) DOI: 10.1016/j.jpha.2015.11.005

16. M.J. Roux, R. Martinez-Maza, A. Le Goff, B. Lopez-Corcuera, C. Aragon, S. Supplisson, J. Biol. Chem. 276 (21), 17699 (2001)

DOI: $10.1074 /$ jbc.M009196200

17. M. Lankisch, P. Layer, R.A. Rizza, E.P. DiMagno, Pancreas, 17(2), 176 (1998)

DOI: 10.1097/00006676-199808000-00011

18. P. Bernfeld, Enzymology, 1, 149 (1955)

DOI: https://doi.org/10.1016/0076-6879(55)01021-5

19. P. Senthilraja, K. Kathiresan, J. Appl. Pharma. Sci. 5(03), 080 (2015)

DOI: $10.7324 / J A P S .2015 .50313$

20. N. Horiuchi, K. Nakagawa, Y. Sasaki, K. Minato, Y. Fujiwara, K. Nezu, Y. Ohe, N. Saijo, Cancer Chemother. Phramocol. 22(3), 246 (1988)

DOI: $10.1007 / \mathrm{BF} 00273419$

21. A.S. Bodkhe, S.S. Patil, M.M. Shaikh, Acta Polo. Pharma. Drug Res. 69(5), 871 (2012)

22. Y. Wang, X. Lin, F. Bai, L. Sun, J. Mol. Sturcture 1149, 379 (2017)

DOI: 10.1016/j.molstruc.2017.07.015

23. G.D. Bajju, P. Sharma, A. Kapahi, M. Bhagat, S. Kundan, D. Gupta, J. Inorg. Chem. (2013).

DOI: https://doi.org/10.1155/2013/982965

24. A.P. Mishra, L.R. Pandey, R.K. Jain, Chem. Sci. Trans. 1(1), 121 (2012)

DOI: $10.7598 /$ cst2012.135

25. V.S. Shivankar, R.B. Vaidya, S.R. Dharwadkar, N.V. Thakkar, Synth. React. Inorg. Metal-Org. Chem. 33 (9), 1597 (2003)

DOI: https://doi.org/10.1081/SIM-120025443

26. S. Tabassum, M. Zaki, F. Arjmand, I. Ahmad, J. Photochem. Photobio. B: Biology. 114, 108 (2012)

DOI: 10.1016/j.photobiol.2012.05.017 
27. Md.A. Hossain, M.S. Islam, Md.A. Alam, T. Sultan, Int. J. Sci. Techno. Res. (IJSTR), $2(7), 210(2013)$

28. S.A. Amolegbe, S. Adewuyi, C.A. Akinremi, J.F. Adediji, A. Lawal, A.O. Atayese, J.A. Obaleye, Arabian J. Chem. 8, 742 (2015)

DOI: http://dx.doi.org/10.1016/j.arabjc.2014.11.040 
Figures

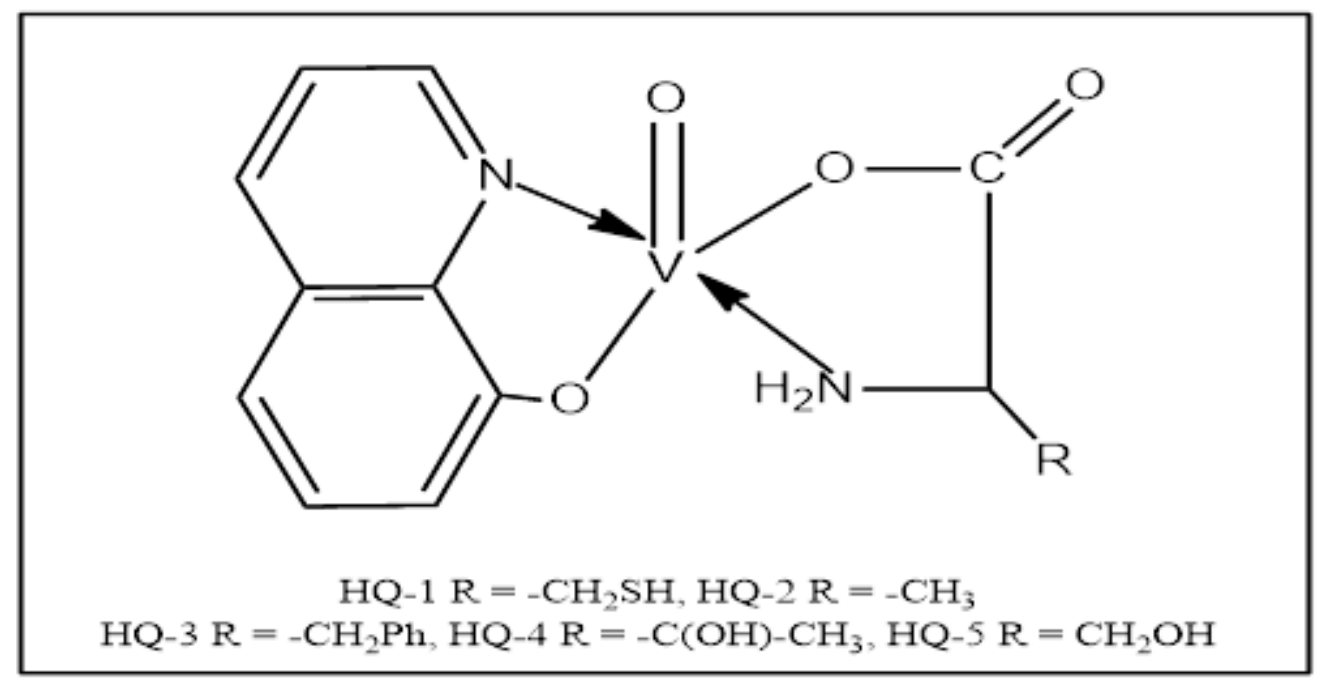

\section{Figure 1}

Generalized proposed structure of all the synthesized mixed ligand complexes
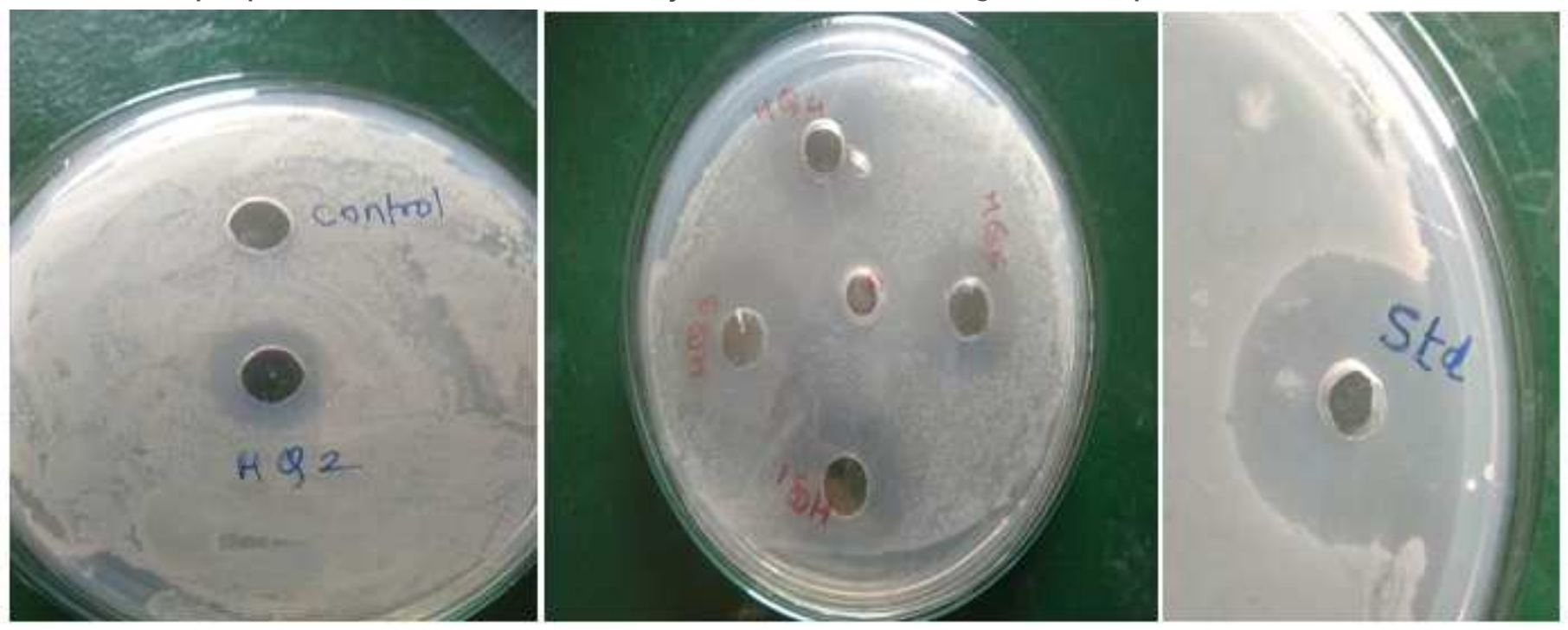

Figure 2

Antibacterial activity against $\mathrm{E}$. coli 

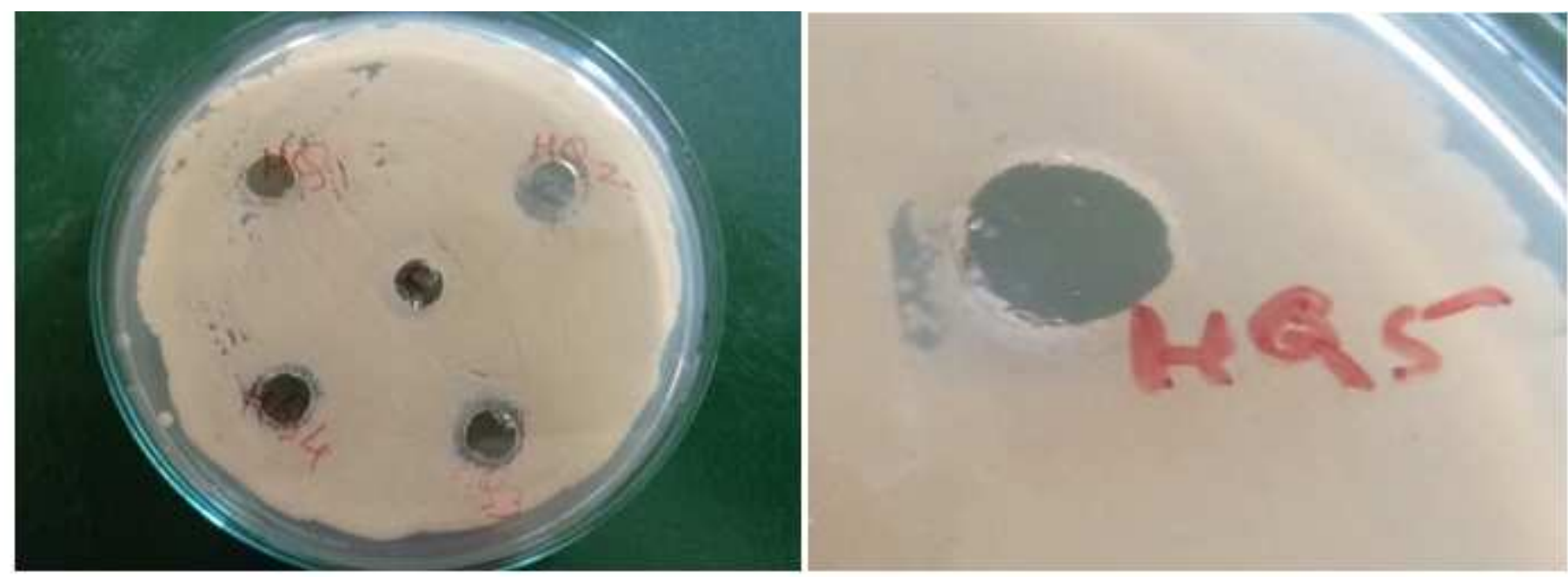

Figure 3

Antifungal activity against C. albicans

\section{Supplementary Files}

This is a list of supplementary files associated with this preprint. Click to download.

- GRAPHICALABSTRACT.jpg

- SUPPLEMENTARYDATA.pdf 